2. Про День Соборності України: Указ Президента України від 13 листопада 2014 р. № 871/2014 / Президент України. Офіційний вісник Президента України. 2014. № 43. С. 44. Ст. 1961.

3. «Досить розділень»: Зеленський привітав українців 3 Днем Соборності. URL: https://www.ukrinform.ua/rubric-polytics/3175809-dositrozdilen-zelenskij-privitav-ukrainciv-z-dnem-sobornosti.html.

4. Кіріченко О.Ю., Куценко В.Й. Соціальна відповідальність як чинник сталого розвитку суспільства. Економіка і менеджмент 2016: перспективи інтегращії та інноваційного розвитку: матеріали між нар. наук.-практ. конф. (Дніпропетровськ, 14-15 квітня 2016 р.). Дніпропетровськ, 2016. С. 11-13.

DOI https://doi.org/10.30525/978-9934-26-040-7-7

\title{
КРИТЕРІЇ РОЗМЕЖУВАННЯ ПРАВА І МОРАЛІ
}

\author{
Кравцова М. О. \\ кандидат юридичних наук,
}

викладач кафедри загально-правових дисииплін

Донецького юридичного інституту

Міністерства внутрішніх справ Украӥни

м. Кривий Ріг, Дніпропетровська область, Украӥна

Приходько А. А.

кандидат юридичних наук,

старший викладач кафедри організачії досудового розслідування

факультету № 1

Криворізького навчально-наукового інституту

Донецького юридичного інституту

Міністерства внутрішніх справ України, капітан поліиіi

м. Кривий Ріг, Дніпропетровська область, Украӥна

Проблема співвідношення моралі і права, як показує загальний огляд теоретичних і літературних спроб ії осмислення, більше цікавила юристів, ніж етикою. Вона для них була і в значній мірі до теперішнього часу залишається однією 3 ключових в теорії права. 
Справа не просто в тому, що даній проблемі приділяється велика увага з боку юристів, більш важливим $є$ те, що існує досить чітко виражена тенденція розглядати ії як базову при усвідомленості сутності права. Співвідношення моралі і права - предмет не тільки наукових дискусій. Ця проблема $є$ також важливим елементом суспільної свідомості. Подібно до того, як фахівці не можуть обійти іiі і не можуть відповісти на питання, що таке право, чи не співвідносячи його з мораллю, так і суспільна свідомість не може не мати своєї певної позиції з даної проблеми.

Історично, починаючи з Аристотеля і закінчуючи Кантом і Гегелем, право розглядалося в рамках філософсько-етичних уявлень про природу людини і в безпосередній співвіднесеності з мораллю. Отже, проблеми співвідношення права і моральності входили в коло базових питань філософії права, яка, до слова, виникла ще в той час, коли право, звичаї, моральність, релігія не були розмежовані і диференційовані [1].

В Античності і Середні століття право вивчалося як щось ідеальне. Вивчення практичної юриспруденції в університетах передбачалося в дуже обмеженому форматі. В основі філософії права лежали спроби виявити ідеал права, до якого слід було відносити правові матеріали Стародавнього Риму. Але справжній розвиток, на думку Р. Паунда, філософії права почалося тоді, коли було поставлено питання права i моралі, коли «відбулося посилене вливання моралі або етичного звичаю в право. Це призвело до необхідності дати раціональне пояснення цього процесу за допомогою з'ясування ступеня схожості звичаїв $\mathrm{i}$ моральних норм. Р. Паунд виділяє ще інший фактор, який сприяє посиленню значимості філософсько-правової думки. Приблизно протягом двох століть, які передували Реформації, юриспруденція була частиною теології, і розробки велися в руслі школи природного права, тому юридична наука (не практикується) розглядалася як гілка етики. Правові норми сприймалися як оформлення моральних норм, а якщо правова норма суперечила духу моральності, то вона не набувала правового характеру і не мала юридичної сили. В першій половині XIX ст. правова наука значно ослабла, і це пов'язано з тим, що на перший план вийшла позитивістська теорія. У зв'язку з цим юридична наука, яка апологезіровала позитивізм, відмовилася від думки, що право має обгрунтування в моральності [4].

B середині XIX ст. з'явився соціологічний напрям, який не заперечував, що фундаментом права є суспільна мораль. 3 подачі Г. Еллінека право декларувалося як мінімум моральності. Мова тут йшла про норми суспільної моралі, які необхідні на конкретній щаблі у 
суспільному розвиткові. Малася на увазі конкретна мораль конкретного суспільства. Г. Еллінек писав, що «великі соціальні сили: релігія, мораль, моральність, словом, вся сукупність культурних чинників і обумовлені ними громадські інтереси і громадські відмінності безперервно впливають на побудову та розвиток права i дають найсильнішу, тільки вдосконалюється іншими факторами гарантію іiі дійсності». Право розглядалося ним як частина моралі. Мораль, тобто етичні звичаї були гарантією громадського порядку [2].

Прихильники неокантіанства (Р. Штаммлер, Г. Ріккерт, В. Вільденбанд) вважали, що право - знаряддя, інструмент справедливості. Тобто право сприймалося як природне право 3 мінливим змістом, але яке має в своїй основі незмінну константу. Прихильники неогегельянства (Б. Кроче, Дж. Джентіле, А. Кожев) стверджували, що право і мораль мають сприяти досягненню мети, а саме будові ідеальної цивілізації. 3 їх точки зору, право підпорядковується моралі, але при цьому право i мораль завжди детерміновані історією конкретних товариств, а отже, 3 необхідністю обумовлюватися часом і місцем [4].

Р. Паунд довів, що доктрина аналітичної юриспруденції може існувати у вигляді теоретичних положень, але практичне іiі застосування виявляється неможливим ні на англо-американської, ні на романо-германської грунті. У ще більшій мірі це відноситься до азіатських країн, які формально живуть за західними зразками (Республіка Корея, Японія). Внутрішня мораль в цих країнах в процесі правозастосування відіграє провідну роль, оскільки саме моральні норми $€$ традиційними регуляторами суспільних відносин.

Але серед вчених-правознавців залишаються сильні і позитивістські позиції, зокрема позитивістська теорія Г. Л. А. Харта, англо-меріканского правознавця, який справив великий вплив на молодого Д. Роулза. Г. Харт вніс великий вклад в розробку теорії методології юриспруденції. Метод Г. Харта полягав в з'єднанні традицій аналітичної філософії XIX ст. 3 концепцією Дж. Бентама. Вчений перебував під сильним впливом Дж. Остіна, крім того, серйозно вивчав праці філософа-лінгвіста Л. Відгенштейна. Згідно концепції останнього, він став застосовувати лінгвістичний метод в юриспруденції. Тобто Г. Харта не можна назвати чистим позитивистом, оскільки він не сприймає командну теорію права (Дж. Остін), вважаючи, що право набагато складніше. Концепція Г. Харта багато в чому схожа 3 утилітаристської позицією Дж. Бентама. [5].

Після наукового спору між професорами Г. Хартом (Оксфорд) i Л. Фуллером (Гарвард), Г. Харт перевів розгляд проблеми 36 
в моральну площину, Л. Фуллер розцінив як з'явилася можливість конструктивного діалогу, тобто «Реального з'єднання предмета спору» між прихильниками і противниками розмежування права i моралі. Отримавши таким чином простір для дискусії, Л. Фуллер поставив своїм завданням довести нездатність юридичного позитивізму гідно служити моральному ідеалу вірності праву. Його відповідь стаття так і називалася: «Позитивізм і вірність праву», в якій він висловив такі позиції: 1) трактування права як діяльності, тобто як якогось процесу, 2) визнання того, що право має цінність навіть тоді, коли воно не досягає своєї мети. Такий підхід дозволив автору відмежувати право як процес, який підпорядковується принципам внутрішньої моралі, від результату цього процесу, заданого зовнішніми по відношенню до права цілями, визначеними їм як зовнішня мораль права. Пізніше ці ідеї були розвинені їм у монографії «Мораль права» [6].

Отже, проаналізувавши історичне виникнення дискурсу щодо розмежування права та моралі та враховуючи сучасні юридичні наукові праці, сформуємо критерії розмежування права та моралі:

1. За походженням: норми права формуються в процесі взаємодії людей (як загальнообов'язкові норми, які гарантує держава), а норми моралі складаються в процесі суспільного життя (з уявлень про справедливість, добро та зло тощо).

2. За сферою регулювання: моральне регулювання має вплив на міжособисте спілкування, норми права регулюють закріплені правом відносини, які мають загальносуспільне значення.

3. За формою вираження: норми права викладені в нормативноправових актах та приписах; норми моралі не мають законодавчої сили та виражені в традиціях, заповідях тощо.

4. За ступенем деталізації: норми права мають чітку конкретизацію, закріплену законодавчо; норми моралі не закріплені законодавчо та не мають чітких вказівок, вони виступають як принципи проголошення безособової повинності формування бажаної поведінки.

5. За засобами забезпечення виконання та специфікою санкцій: додержання моралі залежить від конкретної особи та забезпечується іiї моральними переконаннями та поглядами суспільства на моральні норми; право гарантується державою та забезпечується примусово [4].

Отже, проблематика розмежування права та моралі має давню історію, часто була причиною наукових дискурсів та на даний час хоча і сформована, але існує вирогідність того, що буде ще багато нових поглядів на цю проблематику. 


\title{
Література:
}

1. Арістотель. Політика / Арістотель; пер. 3 давньогрецької, авт. передм. О. Кислюк. - Київ : Основи, 2000. - 239 с.

2. Еллинек Г. Адам в учении о государстве: Библейское предание и политические теории / Пер. с нем. С. М. Роговина. - М.: Изд-е Н. Н. Клочкова, 1909. - 32 с.

3. Кельман М. С Загальна теорія права : підручник / М. С. Кельман, Г. О. Мурашин. - Київ : Кондор, 2002. -353 с.

4. Слабко С. М. Мораль як ціннісний критерій права / С. М. Слабко // Держава та регіони. Серія : Право. - 2014. - № 3. - С. 8-12.

5. Харт Г. Позитивизм и разграничение права и морали // Правоведение. 2005. № 5. С. 104-136

6. Фуллер Л. Позитивизм и верность праву. Ответ профессору Харту // Правоведение. 2005. № 6. С. 124-159.

DOI https://doi.org/10.30525/978-9934-26-040-7-8

\section{ПРАВОВІ ТА ЕТИЧНІ ДИЛЕМИ В ЛГБТ СПІЛЬНОТІ УКРАЇНИ ТА ПОЛЬЩІ}

\author{
Криган Е. P. \\ студентка І курсу денної форми навчання \\ Науковий керівник: Кобан О. Г. \\ доцент кафедри теорії та історії права та держави \\ Інституту права
}

Київського начіонального університету імені Тараса Шевченка

м. Київ, Україна

Актуальність теми. Iз початком становлення і виокремлення четвертого покоління права, стає зрозуміло, що суспільні ідеї та моралі змінюються, суспільство прогресує, еволюціонує, з'являються нові проблеми, які потребують змін, у тому числі й зміни у правовому регулюванні життедіяльності людей. Останнім часом, усе частіше порушується питання ЛГБТ. Оскільки ця тема в Україні та Польщі до другої половини XX століття залишалася під табу, не дивно, що більшість громадян до сих пір не визначилися із власною, гуманною позицією щодо цієї проблеми. 